\title{
PERFORMANCE OF PATIENTS WITH INTERMITTENT CLAUDICATION UNDERGOING PHYSICAL TRAINING, WITH OR WITHOUT AN AGGRAVATION OF ARTERIAL DISEASE. RETROSPECTIVE COHORT STUDY
}

Ruben M. A. Rosoky, Nelson Wolosker, Pedro Puech-Leão

Rosoky RMA, Wolosker N, Puech-Leão P. Performance of patients with intermittent claudication undergoing physical training, with or without an aggravation of arterial disease. Retrospective cohort study. Clinics. 2006;61(6):535-8.

PURPOSE: This was a retrospective cohort study aiming to investigate the clinical outcome of patients with intermittent claudication undergoing physical training in whom there was an aggravation of the arterial disease.

METHOD: Three hundred and sixty-four patients with claudication who presented with femoropopliteal or tibioperoneal obstructions in at least 1 of the lower limbs and who did not have aortic or bilateral iliac obstructions were included. Forty patients developed new stenoses in previously spared arterial segments (confirmed by duplex scanning), which were proximal to preexisting lesions, and formed the progression group, in contrast to the stable group of patients $(n=324)$ who did not exhibit this worsening of the disease. Follow-up was 276 and 277 days for stable and progression groups, respectively. All patients underwent an unsupervised program of submaximal walking 4 days a week. Changes in maximal walking distance at a progressive treadmill test were appraised during follow-up, with special interest directed to the periods between admission, diagnosis of arterial worsening, and the end of follow-up.

RESULTS: Performance was not significantly different between groups during the entire follow-up period. Furthermore, patients with claudication who evolved with progression of their arteriopathy did not present a reduction of their maximal walking distance in response to the development of new arterial lesions at any time during their follow-up.

CONCLUSION: Worsening of the peripheral arterial disease in patients with claudication undergoing physical training, manifested as de novo arterial occlusion in proximal and previously spared segments, does not imply in an impairment of their claudication distance.

KEYWORDS: Intermittent claudication. Treatment outcome. Exercise therapy. Disease progression. Peripheral arterial disease.

\section{INTRODUCTION}

Intermittent claudication is one of the most common clinical manifestations of lower limb ischemia. Patients with intermittent claudication may have major functional deficits, with repercussions for their quality of life. Clinical treatment based on physical training and controlling the

Vascular Surgery Division, São Paulo University Medical School - São Paulo/ SP, Brazil.

Email: drrosoky@terra.com.br

Received for publication on June 07, 2006.

Accepted for publication on July 18, 2006. risk factors for atherosclerosis is the preferred therapeutic approach, with good results when adequately performed. ${ }^{1}$ The main cause of intermittent claudication is atherosclerosis, a disease that frequently affects different arterial levels, and not always at the same time.

For this reason, it is possible to find in the lower limbs involved by the arteriopathy the emergence of new arterial lesions in proximal and previously spared segments. Although the anatomopathological evolution of preexistent stenoses of the superficial femoral artery has already been well documented, ${ }^{2}$ the clinical repercussions of the worsening of the arterial disease in the manner described above 
relative to claudication distance are not yet well established.

While an impairment in claudication distance performance would be expected in this setting, which is encountered rather frequently in a physician's daily work, the only published study was limited by a small sample size and inadequate assessment of outcome variables. ${ }^{3}$

Thus, the objective of this investigation was to determine the influence of the progression of the arteriopathy to proximal and previously spared segments on the claudication distance in patients undergoing to physical training.

\section{METHODS}

This was a retrospective cohort study. Among patients with intermittent claudication admitted during the period between July 1994 and December 2002, we selected those who presented femoropopliteal or tibioperoneal obstructions in at least 1 of the lower limbs and who did not have aortic or bilateral iliac obstruction. There was no bias in patient admission, since participants come directly from the community, without previous referral. All patients underwent similar treatment following the same protocol with the approval of of the university's ethics committee for the analysis of research projects involving experimentation on human beings, in harmony with the Helsinki Declaration of 1975, as revised in 1989. All participants gave written informed consent.

Patients with other disorders that were more severe than intermittent claudication, such as neuropathy, heart failure, and fracture, were not included, neither were those with severe ischemia at the first clinical evaluation (gangrene or ischemic pain while at rest).

An unsupervised program of physical activity, consisting of walking for 40 minutes per day, 4 times a week, was prescribed. Patients were instructed to continue to walk after the onset of typical pain but to stop before the pain reached its maximum intensity. At this point, patients were to rest until the pain subsided and then start walking again to complete the time required. In face-to-face follow-up visits, patients were carefully instructed about the benefits of exercise training. Patients were likewise encouraged to stop smoking and were instructed about the benefits of doing so. No patient was given any type of pharmacologic therapy, but those who were on antiplatelet agents for treatment of cardiac diseases were instructed to continue this therapy. All patients were assessed at admission and in comprehensive visits at months 3 and 6 and at 6-month intervals thereafter.

The ankle-brachial index was evaluated in all patients on entry by Doppler ultrasound (model 1050-C Vascular Mini-Lab, Parks Medical Electronics, Aloha, Oregon).
Maximal walking distance (MWD, also termed claudication distance), the distance walked until claudication pain prevented further walking, was determined on entry and in all serial visits in a progressive treadmill test on a motorized treadmill (Trimline, Hebb Industries, Whitehouse, Texas). This test was carried out at a constant velocity of $3.2 \mathrm{~km} / \mathrm{h}$, initially on a level surface $\left(0^{\circ}\right.$ incline $)$ and then with a progressive increase of $2 \%$ in the incline every 2 minutes. $^{4}$

The extent of arterial disease was appraised by physical examination (palpation of arterial pulses) in all visits, and confirmed by color duplex scanning (model SSH140A, Toshiba, Shibaura, Japan) with transducers of 3.5, 5.0, and $7.5 \mathrm{MHz}$ on entry and when a significant change in the pulse pattern was detected by at least 2 examiners.

Progression of peripheral arterial disease was confirmed when previously spared arterial segments that were proximal to preexisting lesions presented stenoses or occlusions. This procedure enabled the determination of 2 different groups of patients: those who evolved with the progression of the peripheral arterial disease (progression group; $\mathrm{n}=$ 40) and those whose disease remained stable (stable group; $\mathrm{n}=324)$.

For the patients of the progression group, the following variables were calculated:

- Delta 1: MWD measured at the last follow-up visit minus MWD measured immediately before the confirmation of the progression;

- Delta 2: MWD measured at the last follow-up visit minus MWD measured immediately after the confirmation of the progression;

- Delta 3: MWD measured immediately after minus MWD measured immediately before the confirmation of the progression.

The following variable was calculated for the patients of the stable group:

- Delta 1: MWD measured at the last follow-up visit minus MWD measured at entry

Medians and interquartile ranges of the variables described above were calculated. For comparisons of the observed results between groups, the Wilcoxon-MannWhitney test was used. For comparisons of data regarding exclusively the progression group, the Kruskal-Wallis (nonparametric ANOVA) test was used. The value of 5\% was adopted as the level of statistical significance.

\section{RESULTS}

Three hundred sixty-four patients were selected for this investigation. Table 1 shows the demographic data of both groups of patients. Of special interest is the fact that the pro- 
Table 1 - Demographic data of both groups

\begin{tabular}{lll}
\hline & Stable & Progression \\
\hline $\mathrm{n}$ & 324 & 40 \\
Male sex \% & 63 & $45 *$ \\
Mean age (years) & $64(54-72)$ & $64.5(59.8-69)$ \\
Follow-up length (days) & 276 & 277 \\
\hline
\end{tabular}

age expressed as median (interquartile range); $* P=0.417, \chi^{2}=3.94$

portion of men in the progression group was significantly lower than in the stable group. On the other hand, mean age and follow-up length were similar between both groups.

Table 2 shows the results of the variations of the MWD measured at different follow-up times, as described above. There was no significant difference in the values of Delta 1 between groups.

Furthermore, there was no significant difference between Deltas 1, 2, and 3 regarding the progression group.

Table 2 - Variation in the change in maximum walking distance (MWD) during follow-up

\begin{tabular}{lll}
\hline & Stable & Progression \\
\hline Delta 1 (meters) & 59 (range, -50 to 344) & 50 (range, 0 to 300$)$ \\
Delta 2 (meters) & & 0 (range, -57.5 to 157.5) \\
Delta 3 (meters) & & 5 (range, 0 to 150)
\end{tabular}

$P=0.47$ between Delta 1 of stable and progression groups; $P=0.83$ between Delta 1,2, and 3 of the progression group

\section{DISCUSSION}

The results of the present study demonstrate that the worsening of the peripheral arterial disease in claudicanting patients undergoing physical training, manifested as de novo arterial occlusion in proximal and previously spared segments, does not imply in an impairment of their claudication distance. Indeed, claudicants who evolved with progression of their arteriopathy did not present reductions of their maximal walking distance in response to the development of new arterial lesions at any time of their follow-up. This becomes evident when we compare the measurements of MWD immediately after the confirmation of the progression, or even at the last follow-up visit, against MWD measurements made before that confirmation.

The natural history of the walking distance of patients with intermittent claudication is already well documented. There is a consensus that approximately $25 \%$ of those patients present a significant impairment at any time of their lives. This happens in the first year after diagnosis in $7.5 \%$ of the cases and in each of the subsequent years in $2.2 \%$ of the cases ${ }^{1,5}$

In quantitative terms, Aquino $\mathrm{R}$, et $\mathrm{al},{ }^{6}$ studying the natural history of 1244 claudicants for a mean follow-up of 45 months, observed an average reduction in the walking distance reported by the patient (a nonobjective measurement) of approximately 8 meters per year.

The natural history of intermittent claudication is significantly changed when these patients undergo physical training, the benefits of which have already been sufficiently documented. A previous study by our group showed that claudicants who adequately adhere to unsupervised physical training evolve with substantial and predictable improvements. $^{7}$

The progression of the atherosclerotic lesions in claudicants is a neglected theme. The aggravation of previously existing lesions has been well studied in coronary arteries, and it has also been investigated in the lower limbs. Walsh et al, ${ }^{2}$ observed a worsening of superficial femoral artery stenoses in only $28 \%$ and occlusion in only $17 \%$ of the cases in a follow-up period of 37 months. On the other hand, the clinical repercussion of the worsening of this arterial disease has been little addressed until now. A study with 19 claudicants who had femoropopliteal occlusion showed progression of their arteriopathy in 14. Among those, only 2 evolved with an impairment in their maximal walking distance. ${ }^{3}$ However, it is not clear in that investigation how the patients were treated and the method of measurement of MWD.

All the mechanisms involved in the improvement of the claudication distance after exercise could explain the good results seen with patients in the progression group; muscular enzymatic and hemorheologic changes possibly play a major role in this context, ${ }^{8,9}$ as might biomechanical adaptations in the patient gait. ${ }^{10,11}$ Thus, when the aggravation of the arterial disease occurs, the muscle groups affected by the ensuing ischemia would be sufficiently trained to tolerate a lower oxygen supply and maintain their performance unaltered in relation to this event. Clinically, such a situation would have little or no expression.

In conclusion, in light of the results of the present study, it is possible to state that the evolution of claudicants undergoing unsupervised physical training who present a worsening of the arterial disease in their lower limbs characterized by a de novo occlusion in proximal and previously spared segments is benign and similar to that observed in patients whose arterial disease remains stable. Consequently, claudicants with signs of progression of their arteriopathy without manifestations of critical ischemia should not necessarily be considered for invasive treatment and may continue to receive conservative treatment. Understandably, clinical surveillance over those patients should be implemented, not only regarding their arterial disease, but also regarding all other possible systemic repercussions. 
Rosoky RMA, Wolosker N, Puech-Leão P. Desempenho de pacientes com claudicação intermitente submetidos ao treinamento físico em resposta ao agravamento da doença arterial. Estudo retrospectivo de coorte. Clinics. 2006;61(6):535-8.

OBJETIVO: Estudo retrospectivo de coorte para investigar o desfecho clínico de pacientes com claudicação intermitente submetidos a treinamento físico nos quais houve um agravamento da arteriopatia.

MÉTODO: Trezentos e sessenta e quatro pacientes com claudicação que apresentavam obstruções fêmoropoplíteas ou tíbio-peroneiras em ao menos um dos membros inferiores e que não tinham obstrução de aorta ou de ambas artérias ilíacas foram incluídos. Quarenta pacientes desenvolveram novas estenoses em segmentos arteriais previamente poupados (confirmadas por duplex scan), que eram proximais às lesões pré-existentes, e constituiram o grupo progressivo, em contraste com o grupo estável, de pacientes que não apresentou essa piora da doença. O tempo de seguimento foi de 276 e 277 dias para os grupos estável e progressivo, respectivamente. Todos os pacientes passaram por um programa não supervisionado de caminhadas submáximas 4 vezes por semana. Alterações na distância máxima de claudicação num teste de esteira com carga progressiva foram avaliadas durante o seguimento, com interesse especial nos períodos entre a admissão e o diagnóstico da progressão da arteriopatia e o final do acompanhamento.

RESULTADOS: A performance não foi significantemente diferente entre ambos grupos, considerando todo o período de seguimento. Ademais, os claudicantes que evoluíram com progressão da arteriopatia não apresentaram, em nenhum momento de seu seguimento, qualquer redução da distância máxima de caminhada em resposta ao desenvolvimento de novas lesões arteriais.

CONCLUSÃO: A piora da doença arterial periférica em claudicantes submetidos ao treinamento físico, manifestada por novas oclusões em segmentos arteriais proximais previamente poupados, não implica necessariamente numa piora da distância de claudicação.

UNITERMOS: Claudicação intermitente. Desfecho do tratamento. Exercício. Progressão da doença. Doença arterial obstrutiva periférica.

\section{REFERENCES}

1. The TASC Working Group. Management of peripheral arterial disease (PAD); Transatlantic Inter-Society Consensus (TASC). J Vasc Surg. 2000;31:S1-288.

2. Walsh DB, Gilbertson JJ, Zwolak RM, Besso S, Edelman GC, Schneider JR, et al. The natural history of superficial femoral stenoses. J Vasc Surg. 1991;14:299-304.

3. Coran AG, Warren R. Arteriographic changes in femoropopliteal arteriosclerosis obliterans. A five-year follow-up study. N Eng J Med. 1966;274:643-7.

4. Gardner AW, Skinner JS, Cantwell BW, Smith K. Progressive vs. singlestage treadmill tests for evaluation of claudication. Med Sci Sports Exerc. 1991;23:402-8.

5. Jelnes R, Gaardsting O, Jensen KH, Bækgaard N, Tønnesen KH. Fate in intermittent claudication: outcome and risk factors. Br Med J. 1986;293:1137-40.

6. Aquino R, Johnnides C, Makaroun M, Whittle JC, Muluk VS, Kelley ME, et al. Natural history of claudication: Long-term serial follow-up study of 1244 claudicants. J Vasc Surg. 2001;34:962-70.
7. Wolosker N, Nakano L, Rosoky RA, Puech-Leão P. Evaluation of walking capacity over time in 500 patients with intermittent claudication who underwent clinical treatment. Arch Int Med. 2003;163:2296-300.

8. Hiatt WR, Regensteiner JG, Wolfel EE, Carry MR, Brass EP. Effect of exercise training on skeletal muscle histology and metabolism in peripheral arterial disease. J Appl Physiol. 1996;81:780-8.

9. Ernst EE. Matrai A. Intermittent claudication, exercise and blood rheology. Circulation. 1987;76:1110-4.

10. Rosoky RMA, Wolosker N, Muraco BN, Puech-Leão P. Ground reaction force pattern in limbs with intermittent claudication. Eur J Vasc Endovasc Surg. 2000;20:254-9.

11. Womack CJ, Sieminski DJ, Katzel LI, Yataco A, Gardner AW. Improved walking economy in patients with peripheral arterial occlusive disease. Med Sci Sports Exerc. 1997;29:1286-90. 